\title{
Ruthenium-amine complexation for constructing self-assembled molecular films
}

$\operatorname{AUTHOR}(\mathrm{S}):$

MORIGUCHI, Takahiro; MURASE, Kuniaki; SUGIMURA, Hiroyuki

\section{CITATION:}

MORIGUCHI, Takahiro ...[et al]. Ruthenium-amine complexation for constructing self-assembled molecular films. Colloids and Surfaces A: Physicochemical and Engineering Aspects 2008, 321(1-3): $94-98$

\section{ISSUE DATE:}

2008-05-15

URL:

http://hdl.handle.net/2433/97892

\section{RIGHT:}

Copyright (C) 2008 Elsevier B.V.; この論文は出版社版でありません。引 用の際には出版社版をご確認ご利用ください。; This is not the published version. Please cite only the published version. 


\title{
Ruthenium-amine Complexation for Constructing Self-assembled Molecular Films
}

Takahiro Moriguchi, Kuniaki Murase, ${ }^{* *}$ and Hiroyuki Sugimura*

Department of Materials Science and Engineering, Kyoto University, Sakyo-ku, Kyoto 606-8501, Japan

\begin{abstract} $0.1 \mathrm{~V}$ vs. $\mathrm{Ag} / \mathrm{AgCl}\left(3 \mathrm{~mol} \mathrm{dm}{ }^{-3} \mathrm{NaCl}\right)$.

* E-mail: hiroyuki.sugimura@materials.mbox.media.kyoto-u.ac.jp

** E-mail: kuniaki.murase@a0017299.mbox.media.kyoto-u.ac.jp
\end{abstract}

A redox active self-assembled monolayer consisting of ethylenediamine moieties coordinated to $\mathrm{Ru}^{\mathrm{III}}$ ions was prepared through a vapor phase silane coupling of $\mathrm{N}$-(2aminoethyl)-3-aminopropyltrimethoxysilane (AEAPS) molecules onto a $\mathrm{SiO}_{2} / \mathrm{Si}$ substrate, followed by complexation of $\mathrm{Ru}^{\mathrm{III}}$ ions in an aqueous $\mathrm{RuCl}_{3}$ solution. A similar SAM with 3-aminopropyltriethoxysilane did not provide surface $\mathrm{Ru}^{\mathrm{III}}$-complex, indicating that chelation ability plays a key role in immobilizing $\mathrm{Ru}^{\mathrm{III}}$ ions at the surface. The $\mathrm{Ru}^{\mathrm{III}}$ chelated AEAPS-SAM gave a couple of $\mathrm{Ru} / \mathrm{RII} \mathrm{u}^{\mathrm{IV}}$ redox peaks at +1.0 and - 


\section{Introduction}

Thin layers containing metal complex centers, particularly self-assembled monolayers (SAMs) of the complex molecules, have attracted much attention, since such films offer a variety of optical, chemical, electrochemical, and biological functions, based on the redox activities of the complex centers. To fabricate such SAMs, complex molecules with functional group(s) that have a chemical affinity to certain substrates have been synthesized so far. For example, thiol, isonitrile, or related groups were introduced to the molecules to immobilize them on noble metal substrates, and the electrochemical properties of the resulting SAMs, i.e. redox behaviors of center metal ions, have been studied in detail [1-7]. Organosilane, carboxylic and phosphoric acid moieties were applied to the complex molecules being self-assembled on oxide substrates [8-10]. Furthermore, metal-complex molecules having vinyl, hydroxyl or aldehyde groups were immobilized on hydrogen-terminated silicon substrates [11-14].

One promising approach to prepare metal-complex self-assembled layers is to perform complexation of organic molecules with metal ions at a substrate surface. In this approach, organic molecules that have a moiety being served as a ligand site are self-assembled onto a particular substrate surface, and then metal ions are introduced into the SAM of the ligand molecules. This approach can be conducted in the reversal manner as well: A metal ion layer is first deposited on a substrate, and then ligand molecules are coordinated onto the substrate. In these processes, surface-coordination chemistry is an effective principle to promote self-assembling monolayers and multilayers, and a number of reports have been published in this field regarding, for example, phosphonic acid-metal ion [15-22], carboxylic acid-metal ion [23,24], and 
amine-metal ion [25-27] systems.

Organosilane SAMs containing amino moieties are of special interest, since the SAMs have shown abilities as ligands for complex formation with transition metal ions. Various transition metal ions have been shown to be trapped on silica gel coated with an aminosilane SAM $[28,29]$ for the purpose of, for example, the preconcentraion of trace metal ions in subsequent chemical analysis. Palladium ions were demonstrated to be fixed on several types of aminosilane SAMs formed on oxide-covered silicon ( $\mathrm{Si}$ ) substrates through palladium-amine complex formation [30,31]. Such a palladiummodified surface was successfully metallized, since palladium has a catalytic activity for electroless plating. Complex SAMs consisting of metal ions and aminosilane molecules are expected to show electrochemical activities. In particular, SAMs with ruthenium $(\mathrm{Ru})$ ion complex centers are attractive, since such monolayers show excellent redox reversibility and optical functions [32-36].

In this paper, we report the fabrication and electrochemical characterization of a $\mathrm{Ru}^{\mathrm{III}}$ - aminosilane complex monolayer through a surface complexation method. An aminosilane monolayer was first formed on an oxide-covered Si substrate by a vapor phase silane coupling method and, subsequently, modified in an aqueous $\mathrm{Ru}^{\mathrm{III}}$ ion solution for complexation.

\section{Experimental}

N-(2-aminoethyl)-3-aminopropyltrimethoxysilane (AEAPS, Chisso Corp.), 3aminopropyltriethoxysilane (APS, Nacalai Tesque Inc.) and ruthenium(III) chloride hydrate (Nacalai Tesque, Inc.) were used as received. Ultrapure water with a resistivity 
of $18 \mathrm{M} \Omega \mathrm{cm}$ was used throughout this study for the preparation of aqueous solutions and for aqueous cleaning processes. Substrates cut from mirror-finished $\mathrm{Si}(111)$ wafers (Virginia Semiconductor, Inc., arsine-doped, n-type, resistivity 1-4 $\mathrm{m} \Omega \mathrm{cm}$, thickness $350 \pm 25 \mu \mathrm{m})$ were photochemically cleaned by a UV/ozone treatment [37] so as to be completely hydrophilic with water-contact angles close to $0^{\circ}$. It is most likely that the substrate surfaces were terminated with hydroxyl $(\mathrm{OH})$ groups. A thin oxide layer of $c a$. $1.7 \mathrm{~nm}$ in thickness was formed on each of the substrates as confirmed by ellipsometry. Hereafter, we refer to these cleaned $\mathrm{Si}$ substrates as $\mathrm{SiO}_{2} / \mathrm{Si}$.

The $\mathrm{SiO}_{2} / \mathrm{Si}$ substrates were aminosilylated with AEAPS by a vapor phase method [37]. One sample substrate was placed together with a glass cup filled with 0.1 $\mathrm{mL}$ AEAPS liquid diluted with $0.7 \mathrm{~mL}$ absolute toluene into a Teflon ${ }^{\mathrm{TM}}$ container $(\mathrm{mL}$ $=\mathrm{cm}^{3}$ ), which was sealed with a screw cap in a dry $\mathrm{N}_{2}$ atmosphere. The container was then heated for $0.5-72$ hours in an oven maintained at $373 \mathrm{~K}$. After the aminosilylation, each of the samples was sonicated for 20 min successively in absolute toluene, ethanol, $1 \mathrm{mM}$ aqueous $\mathrm{NaOH}$ and $1 \mathrm{mM}$ aqueous $\mathrm{HNO}_{3}$, in that order $\left(\mathrm{M}=\mathrm{mol} \mathrm{dm}{ }^{-3}\right)$. Finally, the samples were rinsed with ultrapure water and then blown dry with a $\mathrm{N}_{2}$ gas stream. For control experiments, APS-modified samples were fabricated: the cleaned $\mathrm{SiO}_{2} / \mathrm{Si}$ substrates were immersed in a solution (APS; $0.02 \mathrm{~mL}+$ absolute toluene; $2 \mathrm{~mL}$ ) for 1 hour under a dry $\mathrm{N}_{2}$ atmosphere. The resulting samples were rinsed with ethanol twice and then baked at $373 \mathrm{~K}$ for $1 \mathrm{~h}$. The baked samples were sonicated in ethanol and pure water, for $10 \mathrm{~min}$ each, in that order, and blown dry with a $\mathrm{N}_{2}$ gas stream. These aminosilylated samples functionalized with AEAPS or APS layer were immersed in aqueous solution containing $1 \mathrm{mM} \mathrm{HCl}$ and $1 \mathrm{mM} \mathrm{RuCl}_{3}$ for 1 hour, after which the samples were sonicated for $10 \mathrm{~min}$ in ultrapure water. 
A spectroscopic ellipsometer (Otsuka Electronics Co., Ltd., FE-5000) was used to estimate the thicknesses of grown films on the samples. Measurements were conducted with an angle of incidence fixed at $70^{\circ}$ in a wavelength range of $250-800$ $\mathrm{nm}$. The actual film thickness was determined by subtracting the thickness of the native $\mathrm{SiO}_{2}$ layer underneath, namely $1.7 \mathrm{~nm}$, from the total. The error of thickness for an identical sample was about $\pm 0.1 \mathrm{~nm}$. Some of the samples were studied by X-ray photoelectron spectroscopy (XPS, Kratos Analytical Ltd., ESCA3400) using Mg K $\alpha$ radiation $(10 \mathrm{~mA}$ and $10 \mathrm{kV})$. The vacuum level under the measurement was kept at around $10^{-7} \mathrm{~Pa}$. The binding energy scales were referenced to $99.5 \mathrm{eV}$ as determined by the locations of the maximum peaks on the $\mathrm{Si} 2 \mathrm{p}$ spectra. Electrochemical measurements were made with an integrated electrochemical analyzer, ALS/CHI model 660C, and a three-electrode cell. Cyclic voltammetry (CV) was carried out in $0.1 \mathrm{M}$ $\mathrm{HClO}_{4}$ aqueous solution, deaerated by $\mathrm{N}_{2}$ gas purging for 30 minutes prior to and during each measurement. A small copper plate with a coated copper lead wire was attached to the backside of the substrate, on which a Ga-In eutectic was rubbed so that the silicon/copper interface would be an ohmic contact. An insulating epoxy resin was then applied to the whole backside and lateral side of the substrate, so that the front face with a fixed area $(1 \mathrm{~cm} \times 2 \mathrm{~cm})$ was exposed to the electrolyte as the surface of the working electrode during cyclic voltammetry. $\mathrm{An} \mathrm{Ag} / \mathrm{AgCl}$ reference electrode immersed in $3 \mathrm{M} \mathrm{NaCl}$ aqueous solution was used for all measurements. A platinum wire was used as a counter electrode.

\section{Results and discussion}


Figure 1 follows the growth of AEAPS layers on the $\mathrm{SiO}_{2} / \mathrm{Si}$ substrates. The growth behavior can be divided into two stages; the first stage with the reaction time of 0 to $3 \mathrm{~h}$ shows a relatively high film growth rate and continues until the thickness becomes about $1 \mathrm{~nm}$ which is almost equal to the molecular length of AEAPS, that is, $0.95 \mathrm{~nm}$ estimated by a molecular mechanics calculation. From the reaction time of $3 \mathrm{~h}$, the second stage, in which the film growth rate is lower than the first stage, starts. It is obvious that the film thicknesses in the second stage are scattered. From these results, we supposed that the AEAPS films have grown as schematically illustrated in Figure 2: In the first stage, AEAPS molecules hydrolyzed with a trace amount of water react with surface $\mathrm{OH}$ groups on a $\mathrm{SiO}_{2} / \mathrm{Si}$ substrate through the silane coupling chemistry as illustrated in Figure 2a, until the surface is fully covered with the AEAPS molecules, resulting in an AEAPS-SAM at the reaction time of $3 \mathrm{~h}$ (Figure 2b). Even after the completion of SAM formation on the substrate surface, AEAPS molecules can continue to deposit due to, for example, the acid-base interaction between the surface amino ($\mathrm{NH}_{2}$ ) groups and $\mathrm{SiOH}$ groups of the hydrolyzed AEAPS molecules. Further deposited AEAPS molecules are accumulated, or "polymerized", yielding an additional layer wherein the molecules are randomly oriented (Figure 2c). It is considered that such a polymerization is responsible for the poor reproducibility of the layer thickness after $3 \mathrm{~h}$, compared to the SAM-formation during the first stage.

Figure 3 shows an XPS N 1s spectrum of the AEAPS-SAM formed by the vapor phase aminosilylation for $3 \mathrm{~h}$. The emergence of the peak at around $400 \mathrm{eV}$ confirms that the aminosilane molecules have been certainly self-assembled onto the substrate. Its surface nitrogen $(\mathrm{N})$ concentration as estimated by XPS was $c a .3 .9$ at.\% which is greater than that of the control sample (APS-SAM formed by the liquid process at a 
deposition time of $1 \mathrm{~h}$ ), that is, $c a .2 .2$ at.\%, since AEAPS contains two $\mathrm{N}$ atoms while APS has only one $\mathrm{N}$ atom.

These two samples, AEAPS-SAM (3 h) and APS-SAM $(1 \mathrm{~h})$, in addition to a bare $\mathrm{SiO}_{2} / \mathrm{Si}$ substrate covered with an oxide layer, were treated in the $\mathrm{RuCl}_{3}$ solution. XPS-Ru 3p spectra of these samples after the $\mathrm{RuCl}_{3}$ treatment are shown in Figure 4. As clearly seen in the spectrum, a certain amount of Ru is present on the AEAPS-SAM sample, while there are no detectable signals from $\mathrm{Ru}$ on both the APS-SAM sample and the bare $\mathrm{SiO}_{2} / \mathrm{Si}$ substrate. The AEAPS-SAM was found to have a strong affinity to $\mathrm{Ru}^{\mathrm{III}}$ ions, probably because the AEAPS-SAM has an ability of chelation which is wellknown to make an equilibrium constant of coordination between ligand molecules and metal ions much larger. In our case, the ethylenediamine parts of two adjacent AEAPS molecules are expected to form a chelate complex with one $\mathrm{Ru}^{\mathrm{III}}$ ion, as schematically illustrated in Figure 5a. Consequently, $\mathrm{Ru}^{\mathrm{III}}$ ions are trapped strongly in the AEAPSSAM. In contrast, there is no indication of the formation of coordination bonds in the case of the APS-SAM as illustrated in Figure 5b. Note that, even in the case of AEAPS-SAM, chlorine, or chloride ions, were not detected by XPS at the surface, suggesting that the presence of $\mathrm{Ru}^{\mathrm{III}}$ ions is not due to a simple physisorption of $\mathrm{RuCl}_{3}$ salt used. The counter anion of the chelated $\mathrm{Ru}^{\mathrm{III}}$ ions will be $\mathrm{OH}^{-}$and $/ \mathrm{or} \mathrm{NO}_{3}^{-}$ions.

This $\mathrm{Ru}^{\mathrm{III}}$-adsorbed AEAPS-SAM sample demonstrated obvious electrochemical activities based on the redox of Ru ions, as shown in Figure 6, in which the CV curve at the first cycle and that after multiple scan cycles are shown (Figure 6a). Although the CV curve at the first cycle shows a maximum peak current of more than $100 \mu \mathrm{A} \mathrm{cm}{ }^{-2}$, the faradaic current markedly decreases when the sample experiences repeated potential cycles. The anodic scan of the first cycle gives two peaks at $+0.65 \mathrm{~V}$ 
and $+1.30 \mathrm{~V}$ vs. $\mathrm{Ag} / \mathrm{AgCl}(3 \mathrm{M} \mathrm{NaCl})$, while that of the second or later cycles shows a single peak at $+1.00 \mathrm{~V}$. The densities of $\mathrm{Ru}$ ions confined at the surface can be estimated by integrating the anode peak areas: Given that the two peaks of the first cycle are both due to the oxidation of $\mathrm{Ru}^{\mathrm{III}}$ to $\mathrm{Ru}^{\mathrm{IV}}$ state (i.e. 1-electrion reaction), the density of $\mathrm{Ru}^{\mathrm{III}}$ ions confined before the first cycle is calculated at $5.3 \times 10^{15} \mathrm{~cm}^{-2}$, which is one order larger than common "monolayer" adsorption. In contrast, the integration of the single peak (the second cycle) from +0.40 to $+1.16 \mathrm{~V}$ suggests that the density of $\mathrm{Ru}^{\mathrm{III}}$ ions after the first cycle decreased to $6 \times 10^{14} \mathrm{~cm}^{-2}$. During the first cycle, weakly adsorbed $\mathrm{Ru}$ ions were most likely desorbed from the surface and, in consequence, only firmly chelated $\mathrm{Ru}$ ions remained. We are thinking that the first and the second anode peaks at the first cycle correspond to tightly and weakly adsorbed Ru ions, respectively. It is expected that the electron transfer from the $\mathrm{SiO}_{2} / \mathrm{Si}$ substrate to weakly adsorbed $\mathrm{Ru}$ ions occurs at potentials positive than that for tightly bound $\mathrm{Ru}$ ions. In fact, the area of the first anode peak is equivalent to the density of $9 \times 10^{14} \mathrm{~cm}^{-2}$, which is close to the density after the first cycle (i.e. $6 \times 10^{14} \mathrm{~cm}^{-2}$ ).

The $\mathrm{CV}$ curve for the Ru-chelated AEAPS-SAM is shown again in Figure $6 \mathrm{~b}$ with an enlarged current scale, together with a CV curve for the AEAPS-SAM without the $\mathrm{RuCl}_{3}$ treatment as a control. In addition to the anode peak at $+1.0 \mathrm{~V}$, the $\mathrm{Ru}-$ chelated SAM shows a broad reduction peak at around $-0.1 \mathrm{~V}$, which might correspond to the reduction of $\mathrm{Ru}^{\mathrm{IV}}$ to $\mathrm{Ru} \mathrm{u}^{\mathrm{III}}$ state. In contrast, the AEAPS-SAM without $\mathrm{Ru}$ ions shows no redox response, hence we conclude here that the redox behavior of the Ruchelated SAM originated from the chelated $\mathrm{Ru}$ ions. The relatively large peak separation between the oxidation and reduction peaks might be due to the insulating oxide layer inserted between the redox active Ru-chelated layer and the substrate $\mathrm{Si}$ 
electrode. Such an insulating layer has an effect to inhibit the electron transfer between the $\mathrm{Ru}$ ions and $\mathrm{Si}$ electrode, resulting in large overpotentials for the electrochemical reactions.

\section{Conclusions}

In conclusion, we have succeeded in fabricating a redox active SAM consisting of ethylenediamine moieties chelating with $\mathrm{Ru}$ ions. The SAM was formed via the vapor phase silane coupling of AEAPS molecules onto a $\mathrm{SiO}_{2} / \mathrm{Si}$ substrate. Subsequently, the complexation of Ru ions was conducted on the AEAPS-SAM sample surface. The Ru-chelated AEAPS-SAM showed oxidation and reduction peaks at +1.0 and $-0.1 \mathrm{~V}$ vs. $\mathrm{Ag} / \mathrm{AgCl}$, respectively, corresponding to the $\mathrm{Ru}^{\mathrm{III}} / \mathrm{Ru}^{\mathrm{IV}}$ redox reaction. Since the fabrication method demonstrated here depends only on the formation of a ligand monolayer with chelation ability through silane coupling chemistry, the method will be useful to provide electrochemical activity to a wide variety of conductive oxides as well as metals and semiconductors covered with a thin oxide layer of a few nm thick or less.

\section{Acknowledgements}

The present work was supported by a Grant-in-Aid for Scientific Research (no. 18656207) and in part by Kyoto University Global COE Program, International Center for Integrated Research and Advanced Education in Materials Science, from the Japan Society for the Promotion of Science (JSPS). 


\section{References}

[1] J. J. Hickman, C. Zou, D. Ofer, P. D. Harvey, M. S. Wrighton, J. Am. Chem. Soc., $111(1989) 7271$.

[2] C. E. D. Chidsey, Science, 251 (1991) 919.

[3] S. E. Creager, G. K. Roew, J. Electroanal. Chem., 370 (1994) 203.

[4] L.-H. Guo, J. S. Facci, G. McLendon, J. Phys. Chem., 99 (1995) 8458.

[5] T. A. Postlethwaite, J. E. Hutchison, K. W. Hathcock, R. W. Murray, Langmuir, $11(1995) 4109$.

[6] J.-B. D. Green, M. T. McDermott, M. D. Porter, J. Phys. Chem., 100 (1996) 13342

[7] S. Ye, Y. Sato, K. Uosaki, Langmuir, 13 (1997) 3157.

[8] Q. Li, S. Surthi, G. Mathur, S. Gowda, Q. Zhao, T. A. Sorenson, R. C. Tenent, K. Muthukumaran, J. S. Lindsey, Appl. Phys. Lett., 85 (2004) 1829.

[9] V. Chukharev, T. Vuorinen, A. Efimov, N. V. Tkachenko, M. Kimura, S. Fukuzumi, H. Imahori, H. Lemmetyinen, Langmuir, 21 (2005) 6385.

[10] N. Araki, M. Obata, A. Ichimura, Y. Amao, K. Mitsuo, K. Asai, S. Yano, Electrochim. Acta, 51 (2005) 677.

[11] Q. Li, G. Mathur, M. Homsi, S. Surthi, V. Misra, Appl. Phys. Lett., 81 (2002) 1494.

[12] K. M. Roth, A. A. Yasseri, Z. Liu, R. B. Dabke, V. Malinovskii, K.-H. Schweikart, L. Yu, H. Tiznado, F. Zaera, J. S. Lindsey, W. G. Kuhr, D. F. Bocian, J. Am. Chem. Soc., 125 (2003) 505. 
[13] R. Zanoni, F. Cattaruzza, C. Coluzza, E. A. Dalchiele, F. Decker, G. Di Santo, A. Flamini, L. Funari, A. G. Marrani, Surf. Sci., 575 (2005) 260.

[14] N. Tajimi, H. Sano, K. Murase, K.-H. Lee, H. Sugimura, Langmuir, 34 (2007) 3193.

[15] H. Lee, L. J. Kepley, H.-G. Hong, T. E. Mallouk, J. Am. Chem. Soc., 110 (1988) 618.

[16] H. E. Katz, M. L. Schilling, C. E. D. Chidsey, T. M. Putvinski, R. S. Hutton, Chem. Mater., 3 (1991) 699.

[17] H. C. Yang, K. Aoki, H.-G. Hong, D. D. Sackett, M. F. Arendt, S.-L. Yau, C. M. Bell, T. E. Mallouk, J. Am. Chem. Soc., 115 (1993) 11855.

[18] S. B. Bakiamoh, G. J. Blanchard, Langmuir, 15 (1999) 6379.

[19] G. A. Neff, M. R. Helfrich, M. C. Clifton, C. J. Page, Chem. Mater., 12 (2000) 2363

[20] A. Hatzor, T. Moav, S. Yoshelis, A. Vaskevich, A. Shanzer, I. Rubinstein, Langmuir, 16 (2000) 4420.

[21] A. Shida, H. Sugimura, M. Futsuhara, O. Takai, Surf. Coat. Technol., 169-170 (2003) 686 .

[22] J. A. Libera, R. W. Gurney, S. T. Nguyen, J. T. Hupp, C. Liu, R. Conley, M. J. Bedzyk, Langmuir, 20 (2004) 8022.

[23] Y. G. Aronoff, B. Chen, G. Lu, C. Seto, J. Schwartz, S. L. Bernasek, J. Am. Chem. Soc., 119 (1997) 259.

[24] H. Yonezawa, K.-H. Lee, K. Murase, H. Sugimura, Chem. Lett., 35 (2006) 1392.

[25] M. Maskus, H. D. Abruña, Langmuir, 12 (1996) 4455. 
[26] M. Altman, A. D. Shukla, T. Zubkov, G. Evmenenko, P. Dutta, M. E. van der Boom, J. Am. Chem. Soc., 128 (2006) 7374.

[27] L. Kosbar, C. Srinivasan, A. Afzali, T. Graham, M. Copel, L. Krusin-Elbaum, Langmuir, 22 (2006) 7631.

[28] L. W. Burggraf, D. S. Kendall, D. E. Leyden, F.-J. Pern, Anal. Chim. Acta, 129 (1981) 19.

[29] W. C. Moreira, Y. Gushiken, O. R. Nascimento, J. Colloid Interf. Sci., 150 (1992) 115.

[30] W. J. Dressick, C. S. Dulsey, J. H. Georger, Jr., J. M. Calvert, Chem. Mater., 5 (1993) 148.

[31] S. L. Brandow, W. J. Dressick, C. R. K. Marrian, G.-M. Chow, J. M. Calvert, J. Electrochem. Soc., 142 (1995) 2233.

[32] H. O. Finklea, L. Liu, M. S. Ravenscroft, S. Punturi, J. Phys. Chem., 100 (1996) 18852.

[33] M. Haga, H.-G. Hong, Y. Shiozawa, Y. Kawata, H. Monjushiro, T. Fukuo, R. Arakawa, Inorg. Chem., 39 (2000) 4566.

[34] N. Terasaki, T. Akiyama, S. Yamada, Langmuir, 18 (2002) 8666.

[35] S. Nitahara, T. Akiyama, S. Inoue, S. Yamada, J. Phys. Chem. B, 109 (2005) 3944.

[36] H. Uehara, M. Abe, Y. Hisaeda, K. Uosaki, Y. Sasaki, Chem. Lett., 35 (2006) 1178.

[37] H. Sugimura, A. Hozumi, T. Kameyama, O. Takai, Surf. Interf. Anal., 34 (2002) 550. 


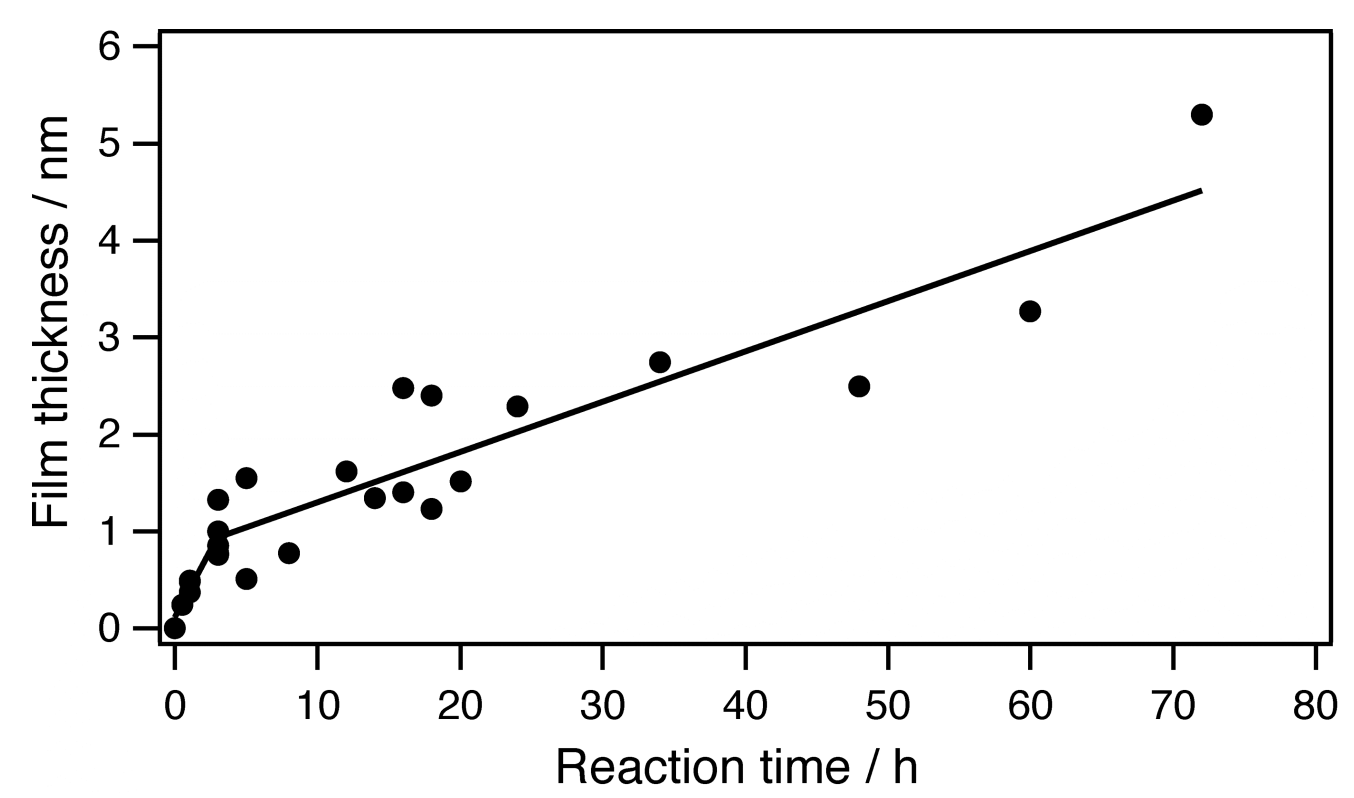

Figure 1. Ellipsometric thicknesses of the AEAPS layers formed on $\mathrm{SiO}_{2} / \mathrm{Si}$ substrate.

(a)

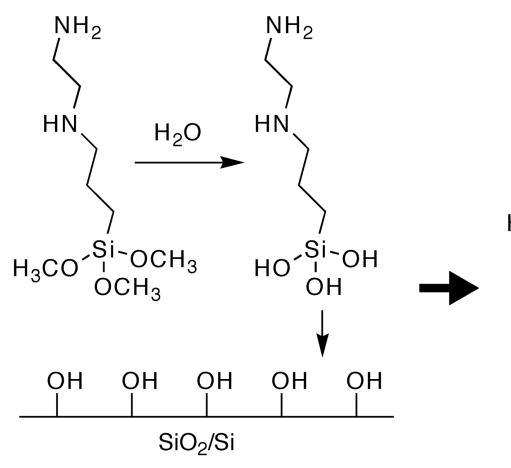

(b)

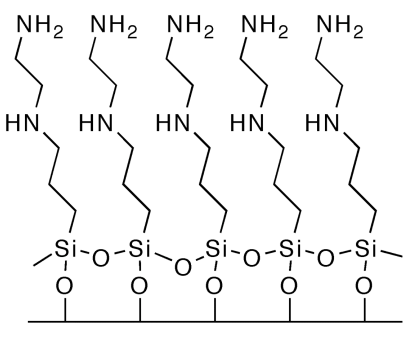

Figure 2. Schematic illustration of the growth behavior of AEAPS layers: (a) Chemical reaction of AEAPS molecules with surface $\mathrm{OH}$ groups on the substrate; (b) AEAPSSAM formed at the first stage; (c) A randomly aggregated layer formed on the AEAPSSAM at the second stage. 


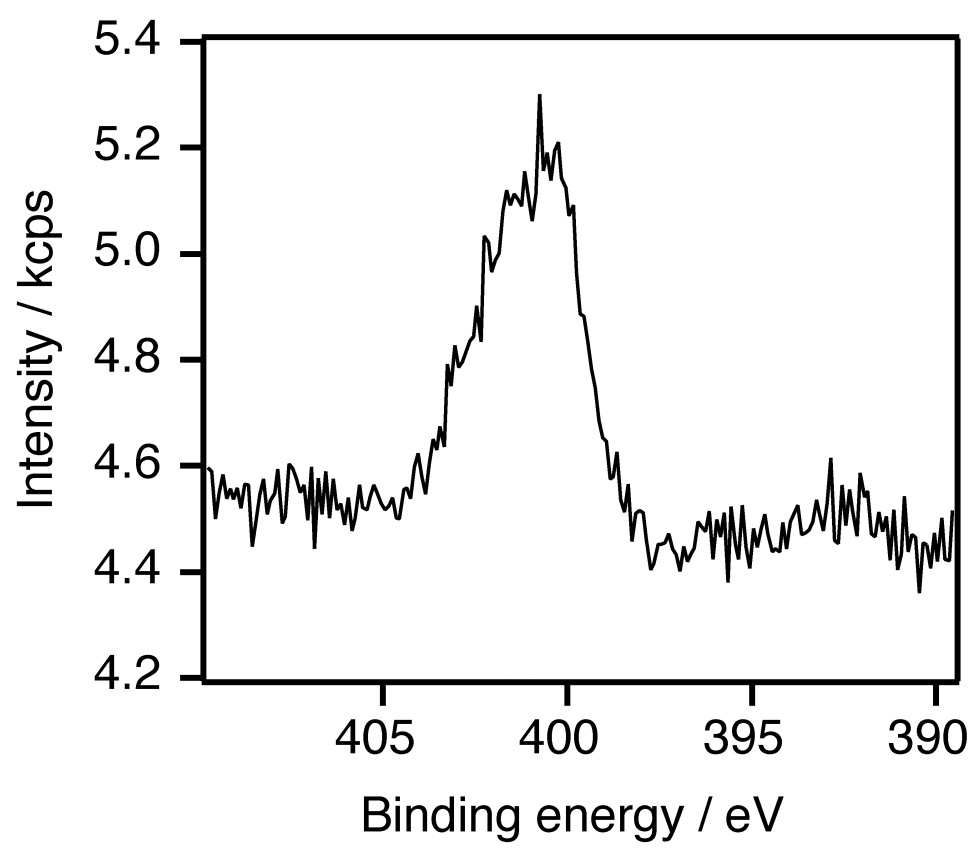

Figure 3. N1s-XPS profile of the AEAPS-SAM.

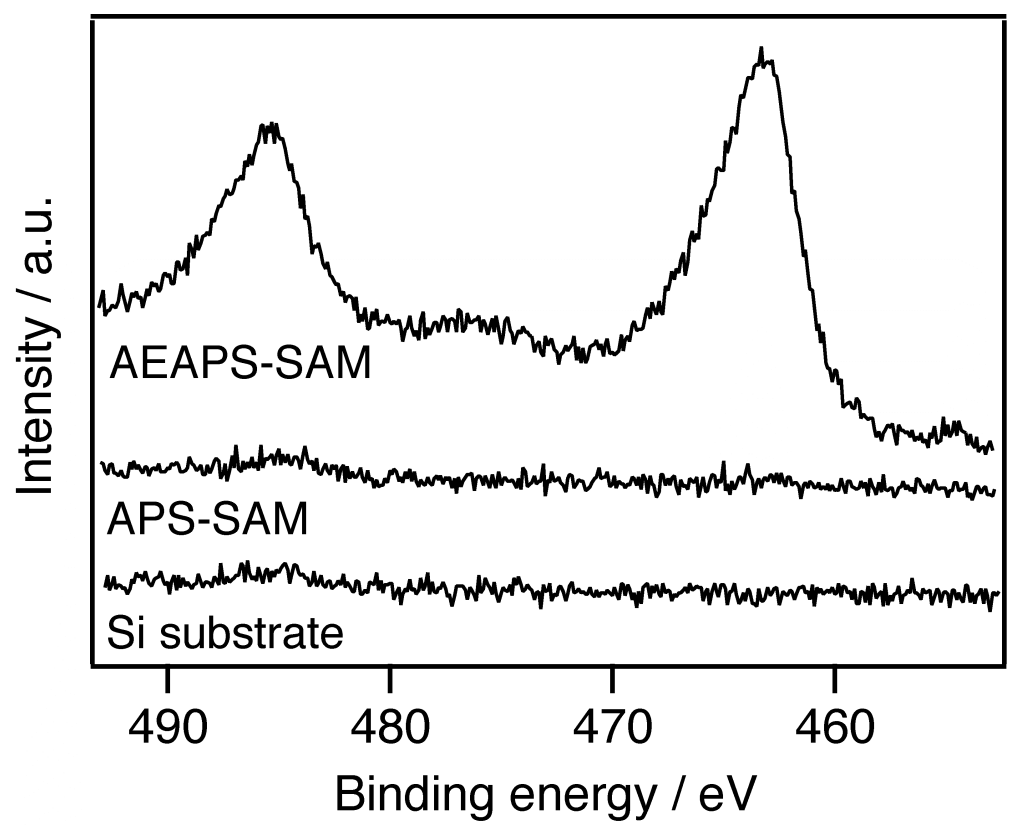

Figure 4. Ru 3p-XPS profiles of the Ru-treated AEAPS-SAM, APS-SAM, and bare $\mathrm{SiO}_{2} / \mathrm{Si}$ substrate. 


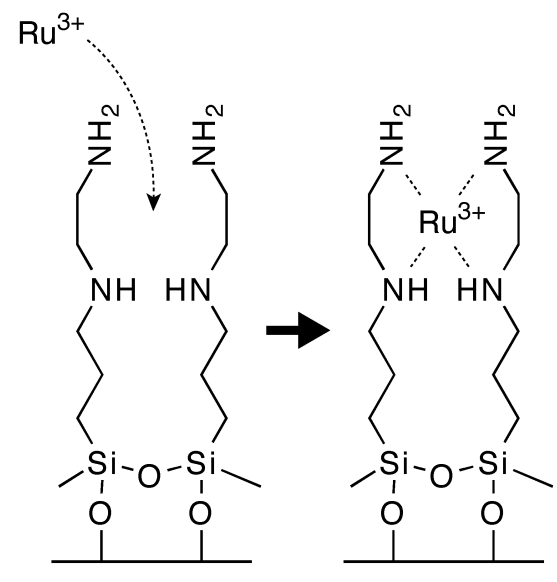

(a)

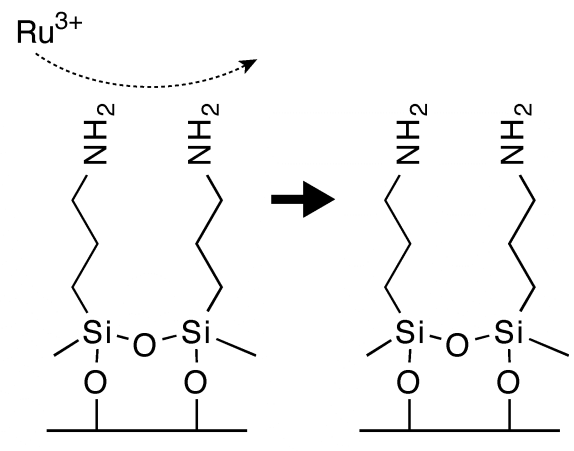

(b)

Figure 5. Schematic illustration of the trapping behavior of $\mathrm{Ru}^{\mathrm{III}}$ ions on (a) AEAPSand (b) APS-SAMs. 

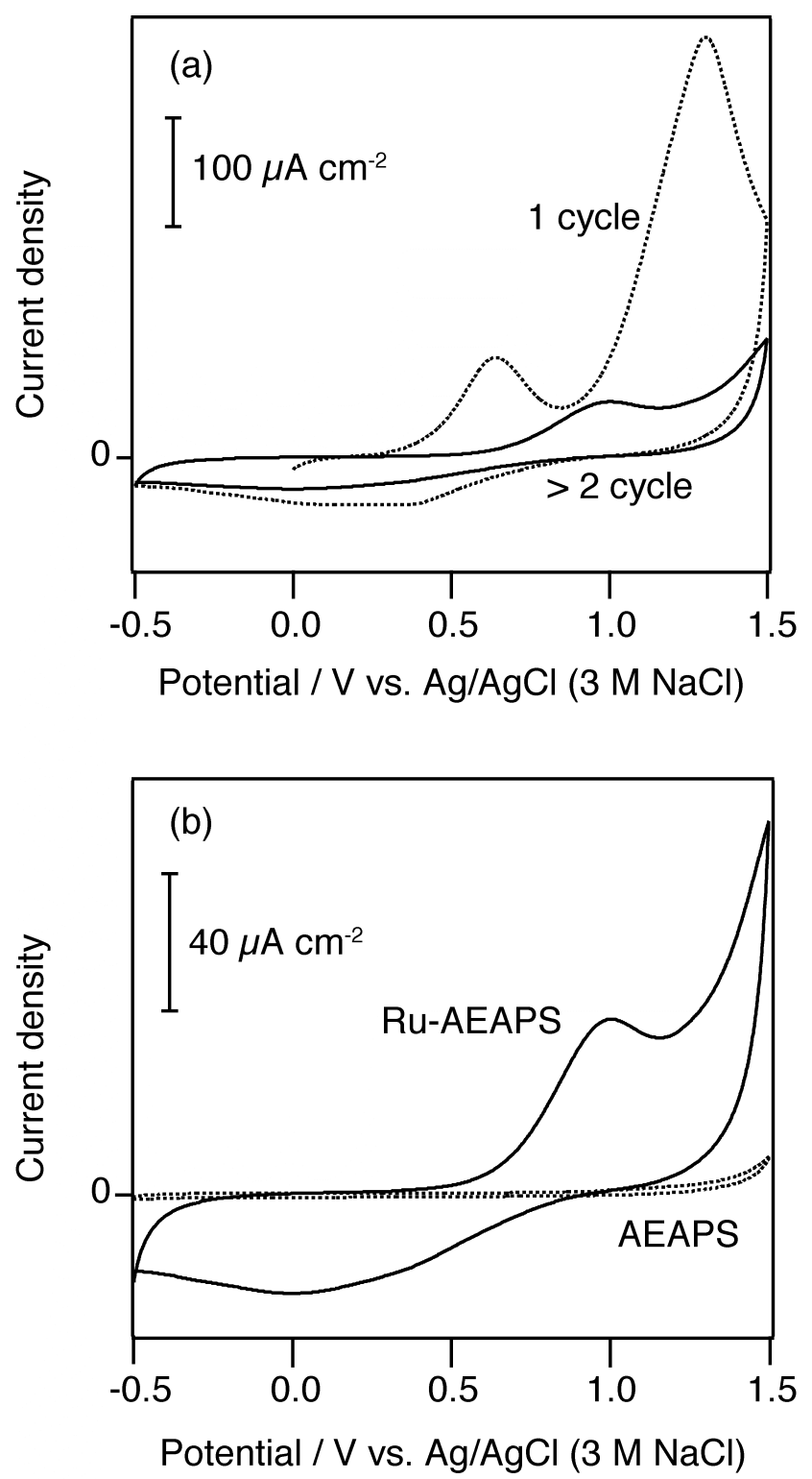

Figure 6. Cyclic voltammograms for (a) Ru-chelated AEAPS-SAM (the first scan and that of after multiple scan cycles) and (b) AEAPS-SAM with and without Ru-chelation (after multiple scan cycles). The potential scan rate was set at $0.1 \mathrm{~V} \mathrm{~s}^{-1}$. 